\title{
Beköszöntő 2014-re
}

\section{Editorial for 2014}

Az év eleje a számadás és tervezés időszaka, a Tér és Társadalom szerkesztőségében is. 2013-ban folytatni kívántuk korábbi munkánkat, nem terveztünk gyökeres változtatásokat. Új borítóval jelentünk meg, de a folyóirat struktúráján nem akartunk változtatni. A terjedelmet csökkenteni szerettük volna, de a sok jó tanulmány és a tematikus szám ezt nem tette lehetővé. A különszám - Váradi Monika vendégszerkesztővel - sikeresnek bizonyult, már a szerkesztőségben is alig maradtak eladatlan példányok. Tartalmi elmozdulást jelentett az elméleti tanulmányok számának növekedése, valamint a külföldiek megjelenése a szerzőink között. A TéT multidiszciplináris jellegét megőriztük.

A szerkesztőket is ösztönözte a „regionális szakma” érezhetö összefogása annak érdekében, hogy időben és gazdag tartalommal jelenhessenek meg számaink. Folyamatosan érkeztek a kéziratok, a múlt évben is több mint 70 tanulmány jelent meg. A szerzők - mint azt a folyóirat végén a részletes jelentés mutatja - az ország különböző egyetemein, föiskoláin, kutatóintézeteiben dolgoznak, tanulnak, a múlt évben több mint 10 tanulmány jelent meg doktoranduszok tollából. A lektorálás fenntartásában felelősségteljes szerep hárult a közel száz lektorra. A magyar nyelvbe zártság és a válság ellenére sem csökkent olvasóink száma. A szerkesztőség összetétele nem változott az elmúlt évben, újdonság, hogy Czirfusz Márton tölti be a föszerkesztő-helyettesi pozíciót. Szomorú esemény, hogy szerkesztőbizottsági tagunk, tisztelt és kedves barátunk, Darrick Danta - aki a California State University professzora volt - meghalt. A TéT külső elismertségének bizonyítéka, hogy a múlt évben sikeresen szerepelt a Nemzeti Kulturális Alap és az MTA folyóirat-kiadási pályázatain, támogatta a Berni Egyetem, a Magyar Regionális Tudományi Társaság és az Aegon, valamint természetesen a folyóirat felelős kiadója, a MTA KRTK. Az előfizetők mellett először járultak hozzá a TéT finanszírozásához a személyi jövedelemadójukból 1\%-ot felajánlók - a Regionális Kutatás Alapítványon keresztül. Támogatásukat 2014-ben is kérjük:

A Regionális Kutatás Alapitvány adószáma: 18056831-2-41

A Magyar Regionális Tudományi Társaság adószáma: 18323038-1-02

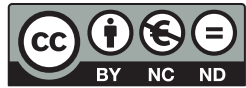


A folyóiratszerkesztés folyamatos üzem: miközben a múlt évről számolunk be, már az első szám nyomdába küldésén dolgozunk, sőt, összeállt a második tematikus szám terve, és már a harmadik-negyedik számhoz gyűjtjük, lektoráltatjuk a kéziratokat. 2013 végén benyújtottunk két új pályázatot a TéT 2014-es finanszírozásához, és reménykedünk, hogy idén a SCOPUS-adatbázisba is bekerülünk a tavaly beadott anyagunk alapján. És természetesen továbbra is várjuk a kéziratokat. 